\title{
Pozitif Algı Ölçeğinin Geçerlilik ve Güvenirlik Çalışması ${ }^{*}$
}

\author{
Tuncay Yavuz ÖZDEMiR, Aslı YILDIZ**
}

Pozitif Algı Ölçeğinin Geçerlilik ve Güvenilirlik Çalışması

Özet

Bu çalışmanın amacı pozitif algı ölçeği geliştirmektir. Bu amaçla 444 öğretmenden oluşan iki farklı örneklemde araştırma gerçekleştirilmiştir. İlk olarak ölçeğin yapı geçerliğini saptamak amacı ile 209 öğretmenden toplanan veriler ile açımlayıcı faktör analizi yapılmıştır. Yapılan faktör analizi sonucunda ölçekte yer alan 15 maddenin üç alt boyutta toplandığı ve toplam varyansın \%67.51'ini açıkladığı tespit edilmiştir. Ölçeği oluşturan maddelerin faktör yükleri 0.45-0.82 değerleri arasında değişmektedir. Ölçeğin yapı geçerliliğini test etmek amacıyla ikinci örneklemde yer alan 235 öğretmenden elde edilen verilerle doğrulayıc faktör analizi yapılmıştır. Doğrulayıcı faktör analizinde üç faktörlü yapısına ilişkin uyum değerlerinin iyi olduğu gözlemlenmiştir. Ölçeğin güvenirliliği için ise Cronbach Alpha katsayısı hesaplanmış ve ölçeğin tamamı için 0.90 olarak ölçülmüştür. Bu değer maddelerin istenilen ölçüde güvenilir olduğunun göstergesidir. Yapılan analizler geliştirilen Pozitif Algı Ölçeği'nin yeterli düzeyde geçerli ve güvenilir bir ölçme aracı olduğunu göstermiştir.

Anahtar Kelimeler: Pozitif Algı, Yönetsel Etkililik, Ölçek Geliştirme

\begin{abstract}
Validity and Reliability Study Of the Positive Perception Scale

\section{Abstract}

Positive perception constitutes the general framework of an individual's self-assessment, as well as the fact that an individual being assessing the others and an individual being assessed by the others. In this context, the effective use of positive perception in each unit of management and its application in motivation management will be one of the decisive factors in terms of the quality of the personnel. As a result of a literature review, it was found that teacher and school principals did not have an adequate assessment instrument which is at a national level for determining their positive perception level. In this context, it is considered that the positive perception scale will provide important contributions to the researches for determining the positive perception levels of the teachers.
\end{abstract}

\section{Giriş}

Her insanın öznel duruşuyla varlık gösterdiği kozmopolit dünya toplumunda algı, bireyleri birbirinden farklı kılan temel faktörlerden biridir. Algılama bireyin bütün yaşantıla-

\footnotetext{
*Bu araştırma; Dr.Öğr.Üyesi Tuncay Yavuz ÖZDEMIR'in danışmanlığında Aslı YILDIZ tarafından yürütülen yüksek lisans tezinden türetilmiştir.

**Tuncay Yavuz ÖzDEMiR, Dr. Öğr. Üyesi, Fırat Üniversitesi Eğitim Bilimleri Enstitüsü, tyozdemir@gmail.com, ORCID ID orcid.org / 0000-0002-5361-7261, Aslı YILDIZ, Doktora Öğrencisi, Fırat Üniversitesi Eğitim Bilimleri Enstitüsü, Eğitim Yönetimi Anabilim Dalı, yildizasli13@gmail.com, ORCID ID orcid.org / 0000-0002-0100-3129
} 
Tuncay Yavuz ÖZDEMIR | Aslı YILDIZ

rının öznel yansıması olarak; dış ortamdan gelen uyarıcıları tanıyıp, anlamlandırıp ve değerlendirmesi şeklinde tanımlanabilir. Beyin, algılama esnasında bireyin içinde bulunduğu durumdan kaynaklı beklentileri, yaşantıları, duyu organlarından gelen farklı duyuları, toplumsal ve kültürel değerleri hesaba katar (Cüceoğlu, 2006, s.118). Bu nedenle algı unsuru çok yönlü bir faktör olup; bireylerin hayata baktıkları pencereleri şeklinde tanımlanabilir.

İnsan duyguları birçok araştırmacının ilgisini çekmiştir. Özellikle İkinci Dünya Savaşı'ndan sonra pozitif psikoloji alanına eğilim kendini göstermiştir. Pozitif psikoloji, olumlu duygulara, deneyimlere, hayatın anlamı ve bunun gibi konulara yoğunlaşmıştır (Uz Baş, 2015 , s.1). Bu bilim dalı potansiyel, yetenek, güç ve güzel deneyimleri geliştiren; geleneksel psikoloji unsurlarını göz ardı etmiş insanların, pozitif yönlerini ön plana çıkarır (Erzen, Çikrikci, 2014, s.198).

Pozitif psikoloji, pozitif deneyimleri üç farklı zaman ölçütünde ele alır, bunlar:

1. Geçmiş; iyi olma ve sosyal doyum kavramlarıla ilgilidir;

2. Şimdi; mutluluk ve akış deneyimi kavramları üzerinde yoğunlaşır;

3. Gelecek; iyimserlik ve geleceğe olumlu bakma kavramlarına hakimdir (Hefferon, Boniwell, 2014, s.3).

Pozitif psikoloji hayatı sadece olumlu yönleriyle değil, olumsuz yönleriyle de kabul ederek bireysel motivasyonu yüksek tutmayı amaçlayan ve örgütsel ilişkilere pozitif algı perspektifli bir yaklaşımı benimsemiştir. Pozitif algıya sahip bireylerin yüksek hedefler koyma konusunda daha motive ve bu hedefleri yerine getirmede daha başarılı oldukları görülmüştür ( Kim, Oh, Chiaburu ve Brown, 2012 ). Pozitif psikolojinin temel çalışma alanı olarak tanımlanan; pozitif kişisel deneyimler, özellikler ve pozitif kurumlarla ilgili bilimsel çalışmaların örgütsel çerçeveyle uygulanması pozitif örgütsel psikolojinin çıkış noktasıdır (Kelekçi, 2015, s.11). Örgüt ve organizasyonların olumlu bakış açısıyla değerlendirilmesi gerektiğini savunan "pozitif örgütsel psikoloji" yaklaşımı ortaya çıkmıştır (Oruç, 2015, s.10).

Pozitif algı, farklılıktan doğan zenginliklerin temelini oluşturan; sürece dayalı bir olgudur. Bu farklılıkların yönetimi, bireyselliği göz önünde bulundurarak işgörenin örgütteki konumuna değer vermek ve işgörene saygı göstermeyi gerektirmektedir (Balyer, Gündüz, 2010. s.27). Bir örgütün nitelikli ve sağlıklı olması, üyelerinin ihtiyaç ve beklentilerinin karşılanması, kendilerini iyi hissetmeleri ile her yönden sağlıklı olmaları durumudur (Cemaoğlu, Şahin, 2007, s.467). Bireyin algılama sürecinde önceki eğitim yaşantısı, toplumsallaştığı kültürel çevre, örf, adet, gelenekler ve inançları biçimlendirici bir role sahiptir ve bu faktörler bireylerarası ilişki ve etkileşimi de büyük ölçüde etkiler (Kepekçioğlu, 2015). 
Kimi bireyler güçlü öz yeterlilik duygusuna sahip olup en zor işlerde bile etkili olacaklarına inanırken; kimileri ise bu inançlar dışında sadece kolay işlerde etkili olabileceklerini düşünmektedirler (Eryılmaz, 2015). Bireyin yaşamında, olumlu duygulanımları, olumsuz duygulanımlarından üstün ve kişinin yaşam niteliğine ilişkin bilişsel tutumu olumlu ise öznel iyi oluşu yüksek olmaktadır (Tuzgöl Dost, 2005, s.104). Aksi durumda kişinin kendisine karşı olan tutumlarının olumsuz bir hal alması, işle ilgili çeşitli alanlarda kendini yetersiz hissetmesi ve çalışanlar arasında bulunan ilişkilerde de başarısızlık duygusuna neden olur (Kayabaşı, 2008, s.195). Sezgin ve Kılınç (2010)'a göre de kişinin karşılaştı̆̆ı zorluklar karşısında ve sosyo kültürel ilişkilerinde kendini yetersiz hissetmesi, kişisel başarısızlığın nedenlerindendir. Pozitif psikoloji insanların psikolojik sağlık açısından kendilerini nasıl koruyacaklarını ifade etmenin yanı sıra, onların duygu bakımından da normalliklerini korumaları ve daha çok pozitif duygulanımlarla yaşamaları gerektiğini söylemektedir (Özasma, 2016, s.141).

Kişinin kendisi ve başkaları ile ilgili olumlu ya da olumsuz algıları, bireysel motivasyonu doğrudan etkileyen faktörlerdendir. Nitekim pozitif algı durumları motivasyon yoğunluğunu belirleyici etkiye sahiptir ( Gaable ve Poole, 2012). Kişilerin üstlendiklerini düşündükleri rol ile yöneticilerinin çalışanlarını büründürdüğü rol arasındaki farklılık, ya da görevi ile belirsizliklerin olması bireyin kendi içinde ya da çevresi ile çatışmasına neden olabilmektedir (Sütlü, 2007, s.58). Bu bağlamda liderlerin çalışanları hakkındaki olumlu ya da olumsuz algısı ve bunu çalışanlarına ne derecede yansıttığı önemlidir. Pozitif algı, bireylerin sosyal ve akademik hayatının büyük bir kısmını geçirdikleri eğitim kurumlarında büyük öneme sahiptir. Okul yöneticilerinin öğretmenlere olumlu ya da olumsuz dönütler vermesi öğretmen motivasyonunu yönlendiren algıların oluşumunu sağlayacaktır. Bu noktada yapılan bir araştırmada olumlu geri bildirimin, olumsuz geribildirime göre hedefe ulaşmada daha motive edici olduğu görülmüştür (Fishbach, Eyal ve Finkelstein, 2010). Nitekim Reaves ve Cozzens' in (2018) yaptıkları bir çalışmada öğretmenlerin güvenli ve destekleyici okul ortamı hakkındaki algıları, içsel motivasyon ve öz yeterlilik algılarını olumlu yönde etkilediği görülmüştür. Pozitif algıların, içsel motivasyonu desteklediğini aynı zamanda sorumlu iş davranışlarının arttırdığı (Isen ve Reeve, 2006) esnek düşünme ve problem çözmeyi kolaylaştırdığını ve yapılacak görevlerin karmaşık, zor ve önemli olduğu durumlarda bile performansı artırdığını göstermektedir (Isen, 2000). Yapılan araştırmalar öğretmenlerin liderlerinden ve yönetimden net beklentilere sahip olmaları içsel motivasyon üzerinde en büyük etkiye sahipken; liderlerinin eğitim davranışlarını aktif bir şekilde gözlemlemelerine imkan vermeleri öz yeterlilikleri üzerindeki en büyük etkiye sahip olduğu görülmüştür (Reaves ve Cozzens ,2018).

Liderliğin doğasında bir etkileme ve yönlendirme potansiyeli mevcuttur. Örgütsel açıdan düşünüldüğünde liderlik; yöneticilerin bireysel ve örgütsel amaçları gerçekleştirmek için çalışanları etkileme ve yönlendirme süreci olarak ifade edilebilir (Kurt, 2014, s.38). Okul yöneticileri, okuldaki madde ve insan kaynaklarını organize eder, çalışanların iş ya- 
Tuncay Yavuz ÖZDEMIR | Aslı YILDIZ

şamında daha nitelikli olması için onları destekler (Aksu, Baysal, 2005, s.109). Bu destek, liderin çalışanlarına güvenmesi ve onları adil koşullarda değerlendirmesi, çalışanlarına vereceği görevlerin en iyi şekilde yerine getirilebileceği inancının olması yani işgörenler hakkında pozitif algıya sahip olması şeklindedir.

Genel olarak pozitif algı bir iletişim biçimidir diyebiliriz. Nitekim iletişimi gerçekleştiren bireylerin birbirlerini ne şekilde algıladığı, onların birbirlerine karşı olan tutumlarını ve iletişimin niteliğini etkilemektedir (Kepekçioğlu, 2015, s.20). Pozitif algı bireyin öz değerlendirmesi, başkalarını değerlendirmesi ve başkaları tarafından değerlendirilmesi durumlarının genel çerçevesini oluşturur. Bu bağlamda pozitif algının yönetimin her biriminde etkin kullanımı ve motivasyon yönetiminde uygulanması işgören niteliği açısından belirleyici faktörlerden biri olacaktır. Yapılan bir çalışmada İşgörenlerin içsel motive olduklarında, faaliyete ilgi duyup zevk aldıkları için bir katılım gösterirken; dışsal olarak motive olduğunda, bireyler ödül almak gibi araçsal ya da diğer nedenlerle faaliyetlere katılım gösterdikleri görülmüştür (Eccles, Wigfield, 2002). Pozitif psikoloji ve pozitif algı son zamanların eğitim anlayışında da etkin olmaya başlamıştır. Bu perspektifle pozitif algı çerçevesiyle eğitim anlayışı, zenginlik ve servetin getirdiği refahtan daha anlamlı kılan yeni bir refah zamanı olarak nitelendirilmiştir (Seligman, Ernst, Gillham, Reivich ve Linkins,2012). Literatür taraması sonucunda öğretmenlerin okul yöneticilerinin kendilerine dönük pozitif algı düzeyini belirlemeye yönelik ulusal düzeyde bir ölçme aracının olmadığı, Icekson\& Pines (2013) tarafından geliştirilen ölçeğin ise öğretmenlere yönelik olmadığı için araştırma amaçlarına uygun olmadığı görülmüştür. Bu bağlamda pozitif algı ölçeğinin öğretmenlerin pozitif algı düzeylerini belirlemeye yönelik araştırmalara önemli katkılar sağlayacağı düşünülmektedir. Bu araştırmada öğretmenlerin pozitif algı düzeylerini belirlemeye yönelik, yeterli düzeyde güvenilir ve geçerli olan bir ölçme aracı geliştirilmesi amaçlanmıştır.

\section{Yöntem}

Bu bölümde çalışma grubu, ölçek hazırlama aşamaları ve yapılan istatistiksel analizlere yer verilmiştir.

\section{1 Çalışma Grubu}

Araştırma 2015-2016 Elazığ ili merkez ilçede görevli ilkokul öğretmenleri üzerinde gerçekleştirilmiştir. Araştırmada temsil edici bir örneklemin geçerli ve en etkili yolu olan basit seçkisiz örnekleme yöntemi (Büyüköztürk, 2016) kullanılmıştır. Araştırma açımlayıcı ve doğrulayıcı faktör analizleri için iki ayrı örneklemde gerçekleştirilmiştir. Pozitif algı ölçeğinin açımlayıcı faktör analizi işlemleri için 121 erkek $(\% 57,89)$ ve 88 kadın $(\% 42,11)$ olmak üzere 209 öğretmene ulaşılmıştır. Doğrulayıcı faktör analizi işlemleri için 119 erkek 
(\%50.64) ve 116 kadın $(\% 49,36)$ olmak üzere 235 öğretmen örnekleme ulaşılmıştır. Çalışma grubuna dahil edilen öğretmenlerin demografik bilgileri Tablo 1 ve Tablo 2'de verilmiştir.

Tablo 1. Açımlayıcı Faktör Analizinde Yer Alan Katılımcıların Demografik Özellikleri

\begin{tabular}{|c|c|c|c|c|}
\hline \multirow{2}{*}{ Cinsiyet } & Erkek & Kadın & & \\
\hline & 121 & 88 & & \\
\hline \multirow{2}{*}{ Mesleki Kıdem } & 1-5 Yıl & 6-10 YII & 11-15 YII & 16-20 YII \\
\hline & 51 & 66 & 57 & 35 \\
\hline
\end{tabular}

Tablo 2. Doğrulayıcı Faktör Analizinde Yer Alan Katılımcıların Demografik Özellikleri

\begin{tabular}{lllll}
\hline \hline \multirow{2}{*}{ Cinsiyet } & Erkek & \multicolumn{2}{l}{ Kadın } & \\
\cline { 2 - 4 } & 119 & 116 & & \\
\hline \multirow{2}{*}{ Mesleki Kıdem } & $1-5$ Yıl & $6-10$ Yıl & $11-15$ Yıl & $16-20$ Yıl \\
\cline { 2 - 5 } & 58 & 62 & 76 & 39 \\
\hline
\end{tabular}

\subsection{Veri Toplama Aracı}

Ölçek Formunun Geliştirilmesi: Öğretmenlerin okul müdür ve müdür yardımcılarının kendilerine ilişkin algıladıkları pozitif algı düzeyleri ile ilgili tutumlarını ölçebilmek amaçlanmıştır. Öncelikle ulusal ve uluslararası alanda pozitif algı kavramıyla ilgili yapılan çalışmalar (Köker, 1991; Peterson, Ramamoorthy, Andrews, Horgan, Talamini, \& Chock,2009; Piff, Purcell, Gruber, Hertenstein, \& Keltner, 2012; Doğan \& Totan, 2013; Boniwell \& Heffron, 2014) titizlikle incelenerek, 25 madde içeren bir madde havuzu hazırlanmıştır. Maddelerin yazım yanlışı ve anlatım bozukluğu içermemesini sağlamak için Türkçe Dili ve Edebiyatı alanında eğitim veren uzmanlardan görüşleri alınarak gerekli düzenlemeler yapılarak, 25 maddeden oluşan ölçeğin ilk taslak formu hazırlanmıştır.

Görüşme formunun uzman görüşüne sunularak fikir birliği sağlanması da veri toplama aracının güvenirliğini sağlayan önemli bir ölçüttür. Bu çerçevede konu ile ilgili olarak Eğitim Bilimleri Bölümünde görev yapan dört öğretim üyesi, Elazığ Bilim ve Sanat Merkezinde görev yapan yönetici ve öğretmenlerin (bir yönetici ve iki öğretmen), Elazığ Rehberlik ve Araştırma Merkezinde görev yapmakta olan uzmanların (iki alan uzmanı) görüşlerine başvurulmuştur.

Uzmanlardan alınan dönütler neticesinde gerekli düzenlemeler yapılmış, bu kapsamda 7 madde uzman görüşü ile çıkarılarak kalan 18 maddeden ölçeğin analizlere dahil edilmesine karar verilmiştir. Maddelerin cevaplanması, ölçeğin yapısı göz önünde bulundurularak 7'li Likert tipindedir (1=Kesinlikle katılmıyorum, $2=$ Kısmen Katılmıyorum, 3=Katılmıyorum, 4=Kararsızım 5= Kısmen Katılıyorum, 6=Katılıyorum, 7=Kesinlikle Katılıyorum). 
Tuncay Yavuz ÖZDEMiR | Aslı YILDIZ

\subsection{Verilerin Analizi}

Uzmanlardan alınan dönütler sonrası ölçek gözden geçirilerek ölçeğe son şekli verilmiştir. Uygulamaya başlamadan önce Etik Kurul ve çalışmanın yürütüldüğü il Milli Eğitim Müdürlüğ̈̈'nden araştırma izinleri alınmıştır.

Faktör analizinde amaç unsuru dikkate alındığında açımlayıcı ve doğrulayıcı olmak üzere iki temel yöntemin varlığı gözlemlenmektedir (DeVellis, 2017). Değişkenler arası ilişkilerin incelenerek ortaya yeni bir yapı koyulmaya çalışılan analizlerde açımlayıcı faktör analizi (AFA); değişkenler arası ilişkilere dair önceden belirlenmiş bir hipoteze ya da kurama uygunluğu sınanmak için yapılan analizlerde ise doğrulayıc faktör analizi (DFA) kullanılmıştır (Can, 2013, s.267).

Açımlayıcı faktör analizi, hakkında bilgi sahibi olmadığımız gizil değişkenler ile gözlenen değiş̧enler arasındaki ilişkiyi kurma maksadı tasarlanan bir analiz çeşididir (Çokluk, Şekercioğlu, Büyüköztürk, 2012, s.189). Faktör analizinin yapılabilmesi için verilerin normal dağılım göstermesi gerekmektedir. Bartlett'in Küresellik değeri hesaplanarak verilerin normal dağılıma uygunluğu dolayısı ile faktör analizine uygunluğu incelenmiştir.

Bu ölçekte üç faktörlü model için uyum ölçekleri incelenmiştir. İstatistiksel analizler kayıp ve uç değerler, tek ve çok değişkenli normallik, doğrusallık ve çoklu bağlantı problemi dikkate alınarak gerçekleştirilmiştir. Bu kapsamda öncelikle veri seti kayıp ve uç değerler açısından incelenmiştir. Kayıp verilere seri ortalaması atanmıştır. Ardından uç değerlerler incelenmiş ve analizleri olumsuz düzeyde etkileyebilecek uç veri saptanmamıştır. Araştırma verileri tek ve çok değişkenli normallik açısından incelenmiş ve araştırma değişkenlerine ilişkin çarpıklık (-0.36 ile 0.58) ve basıklık katsayılarının (-0.69 ile 0.47) kabul edilebilir değerlere sahip olduğu görülmüştür. Ayrıca Saçılma Diyagramı Matrisi incelenmiş ve elips şeklinde dağılımların olduğu görülmüştür. Bu bulgular araştırma verilerinin tek ve çok değişkenli normallik ile doğrusallık varsayımlarını karşıladığını göstermektedir (Çokluk ve diğerleri, 2012). Araştırma verilerinin çoklu bağlantı problemine neden olup olmadığı, değişkenler arası korelasyon değerleri ve VIF ve tolerans değerleri incelenerek değerlendirilmiştir. Çoklu bağlantı problemi değişkenler arasındaki korelasyonun 0.90'dan büyük, VIF değerlerinin 10 'dan büyük ve tolerans değerlerinin 0.10 'dan küçük olması durumunda ortaya çıkmaktadır (Çokluk ve diğerleri, 2012). Araştırmanın bağımsız değişkenleri arasındaki ikili korelasyonlar çoklu bağlantı problemine neden olmamaktadır (tüm ikili korelasyonlarda $r<0.90$ ). Ayrıca bağımsız değişkenlere ait VIF (bağımsız değişkenlere ait tüm VIF değerleri 10'dan küçüktür) ve tolerans değerleri (bağımsız değişkenlere ait tüm tolerans değerleri $0.10^{\prime}$ dan büyüktür) çoklu bağlantı problemi oluşturmamaktadır. $\mathrm{Bu}$ istatistiksel analizler dikkate alınarak, araştırma verileri parametrik istatistiki yöntemlerle çözümlenmiştir.

Hazırlanan maddeler arası ilişkilerin keşfedilmesi için Açımlayıcı Faktör Analizi, keşfedilen ilişkilerin farklı örneklemlere uygulanabilirliğinin tespiti için Doğrulayıcı Faktör Analizi 
yöntemleri kullanılmıştır (Çokluk, Şekercioğlu, Büyüköztürk, 2012, s.275). DFA daha önceki çalışmalara ya da kuramlara dayanarak faktörler ve faktörlerin altında yer alan maddelerin bu faktörlerle ne kadar ilişkili olduğunu sınamaktadır (Çokluk, Şekercioğlu, Büyüköztürk, 2012, s.275-278). Ölçek çalışmalarında AFA yapılarak bulunan sonuçlar DFA yapılarak doğrulanmaktadır. Bu ölçekte üç faktörlü model için uyum ölçekleri incelenmiştir.

\section{Bulgular}

\subsection{Açımlayıcı Faktör Analizine Yönelik Bulgular}

Pozitif algı ölçeğinde yer alan 18 madde üzerinde AFA gerçekleştirilmiştir. Verilerin normal dağılıma uygunluğu test edildikten sonra 18 maddelik pozitif algı ölçeğinin Faktör Analizi için uygun olup olmadığını test etmek için Kaiser-Meyer-Olkin (KMO) katsayısı hesaplanmış ve Bartlett Küresellik Testi yapılmıştır. Faktör analizi uygulanmadan önce örneklemin niteliği için yapılan Kaiser-Meyer-Olkin (KMO) ölçüt değeri 0,91 olarak saptanmıştır. Bu değer örneklemin kapsamının kullanılan örneklem için oldukça uygun olduğunun göstergesidir nitekim KMO değeri 1'e yaklaştıkça örneklem yeterliliği yükselir (Büyüköztürk, Kılıç-Çakmak, Akgün, Karadeniz ve Demirel, 2016, s.135).

Verilerin dağılım durumunu belirlemek için yapılan Bartlett testi sonucunda ( $\times 2=$ $1934,770 . p=, 000$ ) istatiksel olarak dağılımın normal ve AFA için uygun olduğu sonucuna varılmışır. Bartlett testinin \%5 anlamlılık düzeyinde değer alması $(p<0,05)$ elde edilen verilerin faktör analizi için uygun olduğunu göstermektedir. Ölçeğin 18 maddesi faktör sayısı dört olacak biçimde temel bileşenler analizine alınmış ve Varimax (25) eksen döndürmesi gerçekleştirilmiştir.

Ölçekte yer alan maddelerin öz değerleri ve karşıllık geldikleri varyans değerleri birinci faktör için 7,86 ve \% 49,11; ikinci faktör için 1,70 ve \% 10,62; üçüncü faktör için 1,25 ve $\% 7,78$ olarak hesaplanmıştır. Nihayetinde üç faktörlü yapının toplam varyansın $\% 67,51^{\prime}$ ini açıkladığı görülmüştür. Faktör yükleri 0.45-0.82 arasında değişmektedir. Birinci faktör beş maddeden oluşup Etkili iletişim ve İşbirliği (Eii) olarak; ikinci faktör dört maddeden oluşup Sorumluluk Yetisi ve Örgütsel Etkililiğe Katkı Sağlama (SYÖKKS) olarak, üçüncü faktör altı maddeden oluşup Mesleki ve Kişisel Yetkinlik (MKY) olarak adlandırılmıştır. Ölçeğin faktör yapısına ve yük değerlerine ilişkin bulgulara Tablo.3'te yer verilmiştir. 
Tuncay Yavuz ÖZDEMiR | Aslı YILDIZ

Tablo 3. Döndürülmüş Faktör Bileşen Matrisi

\begin{tabular}{lllll}
\hline \hline Madde No & Faktör Varyansları & Faktör 1 & Faktör 2 & Faktör 3 \\
\hline P5 & 4,62 & 0,82 & & \\
P6 & 3,71 & 0,77 & & \\
P7 & 3,42 & 0,72 & & \\
P4 & 4,94 & 0,66 & & \\
P8 & 2,94 & 0,63 & & \\
P17 & & 0,81 & \\
P16 & & 0,75 & \\
P15 & 1,16 & & 0,71 & \\
P18 & & 0,61 & \\
P10 & & & 0,60 \\
P11 & & & 0,78 \\
P12 & 2,15 & & & 0,76 \\
P13 & 1,75 & & 0,62 \\
P14 & 1,48 & & 0,51 \\
P9 & 1,42 & & 0,45 \\
\hline
\end{tabular}

Tablo 3 incelendiğinde birinci faktörü oluşturan maddelerin yük değerlerinin ,63 ile ,82; ikinci faktörü oluşturan maddelerin yük değerlerinin ,61 ile ,81; üçüncü faktörü oluşturan maddelerin yük değerlerinin ,45 ile ,78 arasında değiştiği görülmektedir. Yapılan analizler sonucunda üç maddenin 0,45'ten az faktör yüküne sahip oldukları için ölçekten çıkarılmıştır. Sonuçta 15 maddeden oluşan üç boyutlu bir ölçek elde edilmiştir.

\subsection{Doğrulayıcı Faktör Analizine Yönelik Bulgular}

Ölçek çalışmalarında AFA yapılarak bulunan sonuçlar DFA yapılarak doğrulanmaktadır. Hazırlanan maddeler arası ilişkilerin keşfedilmesi için Açımlayıcı Faktör Analizi, keşfedilen ilişkilerin farklı örneklemlere uygulanabilirliğinin tespiti için Doğrulayıcı Faktör Analizi yöntemleri kullanılmıştır (Çokluk, Şekercioğlu, Büyüköztürk, 2012). DFA daha önceki çaIışmalara ya da kuramlara dayanarak faktörler ve faktörlerin altında yer alan maddelerin bu faktörlerle ne kadar ilişkili olduğunu sınamaktadır (Baş, 2013). Ölçek çalışmalarında AFA yapılarak bulunan sonuçlar DFA yapılarak doğrulanmaktadır. Doğrulayıcı faktör analizi yapılarak, DFA sonuçları standart çözüm şekli aşağıda yer almaktadır.

Ölçeğin tek faktörlü yapısı doğrulayıcı faktör analizi ile test edilmiştir. Modifikasyon yapılmadan değerler incelendiğinde $x 2$ /sd, RMSEA, RMR, GRI ve CFI değerlerinin kabul edilebilir sınırlar içerisinde olduğu, AGFI ve IFI değerlerinin ise kabul edilebilir değerlerin yakın olduğu görülmüştür. Yapılan üç adet modifikasyon işlemi ile tüm değerlerin kabul edilebilir sınırlar içerisinde olduğu saptanmıştır. Ölçme modelinde üç adet modifikasyon 
işlemi sonrasında DFA'ya ilişkin uyum indeksi değerleri incelendiğinde $x 2=144,93$, $s d=52$, $x 2 / s d=2,79$ RMSEA $=0,072, R M R=0,70, G F I=0,93, A G F I=0,90 . C F I=0,95$ ve $\mid F I=0,91$ olarak bulunmuştur. Faktör yükleri öğrencilerinde $0,33-0,67$ arasında değişmektedir. Bu değerlerin tamamının kabul edilebilir sınırlar içerisinde olduğu görülmüştür (Çokluk ve diğerleri, 2012, s.271-272). DFA'da Eii faktörünün dört ve beşinci maddeleri ile beş ve altıncı maddeleri arasında, MKY faktörünün onuncu ve on ikinci maddeleri arasında modifikasyon yapılması önerisi ortaya çıkmış ve düzeltme işlemleri gerçekleştirilmiştir. Üç adet modifikasyon yapıldıktan sonra uyum indeksi değerleri yeniden incelenmiştir. Sonrasında bu uyum indeksi değerleri $x 2=141,93, x 2 / s d=2,78 s d=51, R M S E A=0,080, G F I=0,90$. CFI $=0,90$ ve $|F|=0,90$ olarak saptanmıştır. Faktör yükleri 0,49-0,71 arasında değişmektedir. Bu değerler ölçeğin kullanılabilir uyum indekslerine sahip olduğunu göstermektedir.

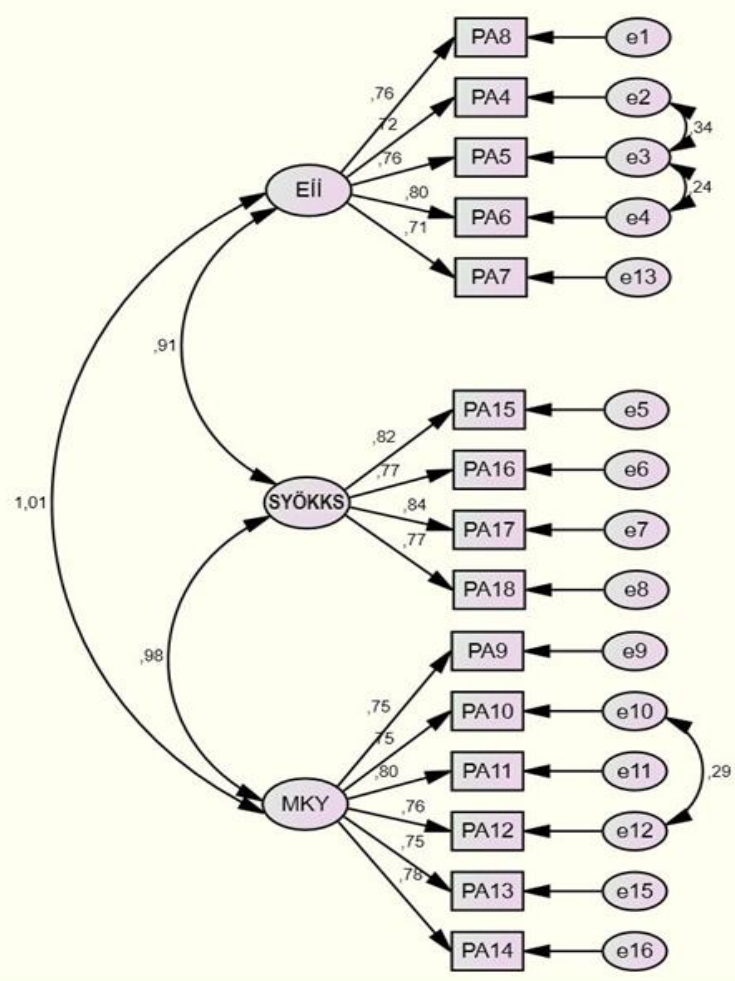


Tuncay Yavuz ÖZDEMIR | Aslı YILDIZ

Şekil 1. DFA Sonuçları Standart Çözüm Şekli

\subsection{Pozitif Algı Ölçeğinin Güvenirlilik Çalışması}

Güvenilirlik kavramı, yapılan ölçümler arası tutarlılık ve kararlılık olarak adlandırılmaktadır (Can, 2014, s.365). Güvenirlilik, testin ölçülmek istenen özelliği hangi boyutta ölçtüğü ile ilgili bir kavramdır (Büyüköztürk ve diğerleri, 2016, s.109). Güvenirliliği belirlemede en sık kullanılan yöntemlerden biri Cronbach Alpha katsayısının hesaplanmasıdır. Bu katsayı aynı zamanda iç tutarlılığın ölçüsüdür. İç tutarlılık güvenilirliği, ölçme aracında bulunan maddelerin kendi aralarında hangi boyutta tutarlılık gösterdiğini test etmek amacıyla kullanılır (Gürbüz, Şahin, 2016, s.323). Güvenirlik bir ölçme aracı için bu değerin en az 0,70 düzeyinde olması gerekir (DeVellis, 2017).

Yapılan analizlerde 1. Faktör için Cronbach Alpha Katsayısı, ,88 düzeyde; 2. Faktör için, ,87 düzeyde; 3. Faktör için Cronbach Alpha Katsayısı, ,94 düzeyinde; ölçeğin tamamı için Cronbach Alpha Katsayısı, ,90 düzeyindedir. Sonuç olarak üç faktörün de güvenilirlik katsayıları nitelikli ve yeterli olduğu tespit edilmiştir.

\section{Tartışma ve Sonuç}

Bu çalışma ile öğretmenler üzerinde kullanılabilecek 15 madde ve üç faktörden oluşan pozitif algı ölçeğinin kullanılabilecek düzeyde geçerli ve güvenilir bir araç olduğu saptanmıştır. Birinci faktör beş maddeden oluşup Etkili İletişim ve İşbirliği (Eii), ikinci faktör dört maddeden oluşup Sorumluluk Yetisi ve Örgütsel Etkililiğe Katkı Sağlama (SYÖKKS), üçüncü faktör altı maddeden oluşup Mesleki ve Kişisel Yetkinlik (MKY) olarak adlandırılmıştır. AFA sonuçlarına göre Pozitif Algı Ölçeğinin Eii boyutunu oluşturan maddelerin yük değerlerinin ,63 ile, 82; (Karagöz, 2016) SYÖKKS boyutunu oluşturan maddelerin yük değerlerinin ,61 ile ,81; (Can, 2014) MKY boyutunu oluşturan maddelerin yük değerlerinin ,45 ile ,78 (Sipahi, Yurtkoru ve Çinko, 2008) arasında değiştiği görülmektedir. AFA ile keşfedilen ilişkilerin farklı örneklerde uygulanabilirliğini belirlemek için yapılan DFA işleminde üç adet modifikasyonla tüm değerlerin kabul edilebilir aralıkta olduğu ve yeterli düzeyde uyum indekslerine sahip olduğu belirlenmiştir. Araştırma ile elde edilen bu bulgular ışığında geliştirilen pozitif algı ölçeğinin yeterli düzeyde geçerli ve güvenilir bir ölçme aracı olduğu belirlenmiştir. Pozitif psikoloji ile ilgili çalışmalar Dünya literatüründe dahi oldukça yenidir (Demir ve Kutlu, 2016a). Bu alandaki çalışmaların geçmişi henüz yarım asrı dahi bulmamıştır. Bu kapsamda düşünüldüğünde alana katkı sağlayacak, olgulara farklı bir bakış açısıyla yaklaşılmasını sağlayacak yeni çalışmaların önemli olduğu değerlendirilmektedir (Demir ve Kutlu, 2016b; Yavuz, 2019). Dolayısıyla bu alanda geliştirilecek bir ölçme aracının sonraki araştırmacılara yeni çalışmalar yapma fırsatı doğuracağı beklenmektedir. 
Pozitif algı ölçeği, bireylerin pozitif algı tutumlarını ölçmek amacı ile birçok farklı çalışmada kullanılabilir.

\section{Kaynaklar}

Aksu, A. ve Baysal, A. (2005). İlköğretim Okulu Müdürlerinde Tükenmişlik. Kuram Ve Uygulamada Eğitim Yönetimi, 41, 7-24.

Alice M. Isen, A.M. \& Reeve, J. ( 2006). The Influence of Positive Affect on Intrinsic and Extrinsic Motivation: Facilitating Enjoyment of Play, ResponsibleWork Behavior, and Self-Control. Motivation and Emotion, 29(4), 297-325.

Baktaş, H. (2015). İkili Değişkenler İçin Faktör Analizi: Çalışma Yaşamı Kalitesi Üzerine Bir Uygulama. Doktora Tezi. İstanbul Üniversitesi Sosyal Bilimler Enstitüsü, İstanbul.

Balyer, A. ve Gündüz, Y. (2010). Yönetici ve Öğretmenlerin Okullarında Farklılıkların Yönetimine ilişskin Algılarının İncelenmesi. M.Ü. Atatürk Eğitim Fakültesi Eğitim Bilimleri Dergisi, 32, 25-43.

Baş, T. (2013). Anket: anket nasıl hazırlanır? Anket nasıl uygulanır? Anket nasıl değerlendirilir? Ankara: Seçkin Yayınevi. Büyüköztürk, ş. (2016). Sosyal Bilimler İçin Veri Analizi El Kitabı. (22).Ankara, Pegem Akademi.

Boniwell, I., \& Heffron, K. (2014). Pozitif Psikoloji Kuram, Araştırma ve Uygulamalar. (Çev.: tayfun Doğan) Ankara: Nobel Akademik Yayınclık.

Büyüköztürk, Ş. (2016). Sosyal Bilimler İçin Veri Analizi El Kitabı. (22).Ankara, Pegem Akademi.

Büyüköztürk, Ş. , Kılıç Çakmak, E. , Akgün, Ö. E. , Karadeniz, Ş. ve Demirel, F. (2016). Bilimsel Araştırma Yöntemleri. (20). Ankara, Pegem Akademi.

Can, A. (2013). SPSS İle Bilimsel Araştırma Sürecinde Nicel Veri Analizi. (1). Ankara, Pegem Akademi.

Can, A. (2014). Spss İle Bilimsel Araştırma Sürecinde Nicel Veri Analizi. (2). Ankara, Pegem Akademi.

Cemaloğlu, N. ve Erdemoğlu Şahin, E. (2007). Öğretmenlerin Mesleki Tükenmişlik Düzeylerinin Farklı Değişkenlere Göre İncelenmesi. Kastamonu Eğitim Dergisi, 15(2), 465-484.

Cüceloğlu. D. (2006). İnsan Ve Davranışı. (15). İstanbul, Remzi Kitapevi. Çokluk, Ö. , Şekercioğlu G. ve Büyüköztürk Ş. (2012). Sosyal Bilimler İçin Çok Değişkenli İstatistik SPSS Ve LISREL Uygulamaları.(2). Ankara, Pegem Akademi.

Dağlı, A., ve Baysal, N. (2016). Yaşam Doyumu Ölçeğinin Türkçe'ye Uyarlanmasi: Geçerlik Ve Güvenirlik Çalişmasi. Elektronik Sosyal Bilimler Dergisi, 15(59). 
Tuncay Yavuz ÖZDEMIR | Aslı YILDIZ

Demir, Y., ve Kutlu, M. (2016a). The Relationship between Loneliness and Depression: Mediation Role of Internet Addiction. Educational Process: International Journal, 5(2), 97- 105. DOI: 10.12973/edupij.2016.52.1

Demir, Y., ve Kutlu, M. (2016b). Üniversite öğrencilerinde sosyal etkileşim kaygısı ile mutluluk arasındaki ilişki: yalnızlığın aracı rolü. Gazi Üniversitesi Gazi Eğitim Fakültesi Dergisi, 36(1), 195210.

DeVellis, R.F. (2017). Ölçek Geliştirme Kuram ve Uygulamalar- ScaleDvelopment. Ankara, Nobel Akademik Yayıncılık.

Dogan, T., ve Totan, T. (2013). Psychometric properties of Turkish version of the Subjective Happiness Scale. The Journal of Happiness \& Well-Being, 1(1), 21-28.

Dönmez, O. (2015). Sınıf Öğretmeni Adaylarının Çocukların Karşılaştığı Çevrimiçi Risklere Yönelik Algılarının Çeşitli Değişkenler Açısından İncelenmesi. Doktora Tezi, Anadolu Üniversitesi, Eğitim Bilimleri Enstitüsü, Eskişehir.

Eccles S. J. \& Wigfield, A. (2002). Motıvatıonal Belıefs, Values, And Goals. Annu. Rev. Psychol, 53:109-32.

Eryllmaz, A. (2015). Positive Psychology in the Class: The Effectiveness of a Teaching Method Based on Subjective Well-Being and Engagement Increasing Activities. International Journal of Instruction, 8(2).

Erzen, E. ve Çikrikci, Ö. (2014). The Turkish Positive Perception Scale: A Contribution to its Validity and Reliability. Journal Of Education And Human Development September, 3(3), 197-203.

Eva Kyndt, E. , Elisabeth Raes, E., Dochy, F. \& Janssens, E. (2012). Approaches to Learning at Work: Investigating Work Motivation, Perceived Workload and Choice Independence. Journal of Career Development ,40(4) , 271-291.

Fishbach, A. , Eyal, T. \& Finkelstein S. R. ( 2010). How Positive and Negative Feedback Motivate Goal Pursuit. Social and Personality Psychology Compass , 4(8), 517-530.

Gürbüz, S. ve Şahin, F. (2016). Sosyal Bilimlerde Araştırma Yöntemleri Felsefe- Yöntem- Analiz. (3). Ankara, Seçkin Yayıncılık.

Hefferon, K. \& Boniwell, I. (Edt. Tayfun Doğan). (2014). Pozitif Psikoloji Kuram Araştırma ve Uygulamalar. (1). Ankara. Nobel Yayıncilık.

Icekson, T., \& Pines, A.M. (2013). Positive perception: A threedimensional model and a scale. Personality and Individual Differences, 54(1), 180-186.

Isen, A.M. (2000). Positive affect and decision making. In M. Lewis \& J. Haviland-Jones Handbook of emotions, 2nd Edition , s: 417-435. NY: Guilford. 
Karagöz, Y. (2016). SPSS ve AMOS 23 Uygulamalı İstatiksel Analizler. (1). Ankara. Nobel Yayınclık.

Kayabaşı, Y. (2008). Bazı Değişkenler Açısından Öğretmenlerin Mesleki Tükenmişlik Düzeyleri. Sosyal Bilimler Dergisi, 20. 191-212.

Kelekçi, H. (2015). Öğretmenlerin Pozitif Psikolojik Sermayeleri Ile Yeterlik İnançları Arasındaki Ilişki. Yüksek Lisans Tezi, Dumlupınar Üniversitesi, Eğitim Bilimleri Enstitüsü, Kütahya.

Kepekcioğlu, E.S. (2015). Üniversite Öğrencilerinin Öğretim Elemanlarının İnanııırlığı Algısı ve Sınıfta Adalet Algısı Arasındaki İlişki. Abant İzzet Baysal Üniversitesi, Eğitim Bilimleri Enstitüsü, Bolu.

Köker, S. (1991). Normal ve sorunlu ergenlerin yaşam doyumu düzeyinin karşılaştırılması. Yayımlanmamış Yüksek Lisans Tezi, Ankara Üniversitesi, Sosyal Bilimler Enstitüsü, Ankara

Kurt, F. (2014). Orta Öğretim Kurumlarındaki Öğretmenlerin Kurum İçi Iletişim Algılarının Kurumsal İtibar Algıları Üzerindeki Etkisi: Bir Araştırma. Okan Üniversitesi, Sosyal Bilimler Enstitüsü, Kocaeli.

Kwanghyun, K., Oh, I., Chiaburu, D. S. \& Brown, K. G. (2012). Does Positive Perception of Oneself Boost Learning Motivation and Performance?. International Journal of Selection and Assessment,20 (3).

Oruç, E. (2015). Pozitif Psikolojik Sermayenin Politik Davranışlara Etkisi: Akademisyenler Üzerine Bir Araştırma. Doktora Tezi, Sakarya Üniversitesi, Sosyal Bilimler Enstitüsü, Sakarya.

Özasma, H.í. (2016). Pozitif Psikoloji ve İslam Düşünürlerinde Erdemler. Ankara Üniversitesi Sosyal Bilimler Enstitüsü, Ankara.

Peterson, C.Y., Ramamoorthy, S., Andrews, B., Horgan, S., Talamini, M., \& Chock, A. (2009). Women's positive perception of transvaginal NOTES surgery. Surgical endoscopy, 23(8), 17701774.

Philip A. Gable, P.A. \& Poole, B.D. (2012). Time Flies When You're Having Approach-Motivated Fun: Effects of Motivational Intensity on Time Perception. Psychological Science, 23(8), 879886.

Piff, P.K., Purcell, A., Gruber, J., Hertenstein, M.J., \& Keltner, D. (2012). Contact high: mania proneness and positive perception of emotional touches. Cognition \& Emotion, 26(6), 11161123.

Reaves, S.J. ve Cozzens, J.A. (2018). Teacher Perceptions of Climate, Motivation, and Self-Efficacy: Is There Really a Connection. Journal of Education and Training Studies, 6 (12).

Seligman, M.E.P., Ernst, R.M., Gillham, J. ,Reivich, K. \& Linkins, M. (2012). Positive education: positive psychology and classroom interventions. Oxford Review of Education, 7, 31-41. 
Sezgin, F. ve Kılınç A.Ç. (2012). İlköğretim Okulu Öğretmenlerinin Mesleki Tükenmişlik Düzeyleri İle Örgütsel Vatandaşlık Davranışları Arasındaki ilişki. Ahi Evran Üniversitesi Kırşehir Eğitim Fakültesi Dergisi (KEFAD), 13 (3), 103-127.

Sipahi, B., Yurtkoru, E.S., \& Çinko, M. (2008). Sosyal bilimlerde SPSS'le veri analizi. İstanbul: Beta Basım Yayım Dağıtım.

Sütlü, T. (2007). Örgütsel Çatışma ve İşgören Üzerine Etkileri. Yüksek Lisans Tezi, Marmara Üniversitesi, Sosyal Bilimler Enstitüsü, İstanbul.

Taştan, Ç. (2012). Bir Pozitif Psikoloji Kavramı Olarak Örgütle Özdeşleşmenin Psikolojik Güçlendirme Algısı ve Gönüllü Performans Davranışı Arasındaki ilişkide Ara Değişken Rolünün Değerlendirilmesi: Gıda Sektöründe Yapılan Bir Araştırma. Organizasyon Ve Yönetim Bilimleri Dergisi, 4(1), 1309-8039.

Tuzgöl, M.D. (2005). Öznel İyi Oluş Ölçeğinin Geliştirilmesi: Geçerlik Ve Güvenirlik Çalışması. Türk Psikolojik Danışma ve Rehberlik Dergisi, 3 (23), 103-111.

Uz Baş, A. (2015). Assesment Of PozitivePsychology Course AccordingToCommentsAnd Life SatisfactionLevels Of CounselorCandidates. Journal Of EducationAnd Training Studies , 4(3).

Yavuz, C. (2019). Does internet addiction predict happiness for the students of sports high school? International Online Journal of Educational Sciences, 11(1), 91-99. 